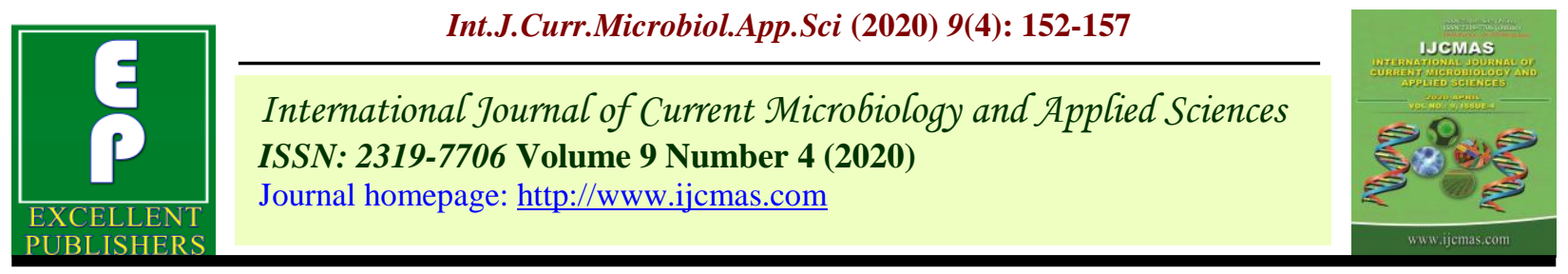

Original Research Article

https://doi.org/10.20546/ijcmas.2020.904.019

\title{
Assessment of AM Fungi Colonization and Spore Population in Different Mungbean Growing Areas of Punjab, India
}

\author{
Amandeep Singh ${ }^{1 *}$, Daljeet Singh Buttar ${ }^{1}$ and Randeep Singh ${ }^{2}$ \\ ${ }^{1}$ Department of Plant Pathology, Punjab Agricultural University, Ludhiana-141 004, India \\ ${ }^{2}$ PG Department of Agriculture, Khalsa College Amritsar-143002, India \\ *Corresponding author
}

A B S T R A C T

\begin{tabular}{|l|}
\hline K e y w o r d s \\
AM fungi, \\
colonization, \\
Ferozepur, Kharif, \\
Mungbean, Spring, \\
Spore populations
\end{tabular}

Arbuscular mycorrhizal fungi (AM fungi) have been found associated with a wide variety of agricultural and horticultural crops, but in legumes it occurs widely. AM fungi are cosmopolitan and ubiquitous in nature under different ecosystems. Different Mungbean growing areas of the Punjab were surveyed to observe the AM fungus colonization with Mungbean and spore population in rhizosphere soil of the crop. The samples from Ferozepur district showed maximum colonization of 80 per cent followed by 78 and 76 per cent colonization of the samples collected from Faridkot and Tarn-Taran districts during spring 2017, respectively. Similarly, in kharif 2017, maximum mycorrhizal colonization was 78 per cent in samples collected from Ferozepur district followed by 77, 69, 60 and 58 per cent colonization in the samples of Faridkot, Moga, Ludhiana and Patiala districts, respectively. Similar trend has been observed in spore population in different districts of Punjab during spring and kharif season. It has been observed that the variance in root colonization and spores population of AM Fungi mainly is due to the different types of soils in different regions of Punjab.

\section{Introduction}

Mycorrhiza is a symbiotic mutualistic relationship between fungus and plant roots. It was considered as a very important symbiotic relationship between microorganisms and higher plants. The Arbuscular Mycorrhizal (AM) fungus is widely distributed in natural and agricultural environments and had been found associated with more than 90 per cent of vascular plants and 80 per cent of land plants (Wand and Qiu 2006). Arbuscular mycorrhizal fungi (AMF) colonize the roots of host plants and enhanced the surface area of roots, which directly contributed to the improved uptake of nutrients like N, P etc and enhanced the growth parameters of plants. AM fungi colonization improved the nutrient uptake and growth of Mungbean plants had been reported by Manke et al., (2008) and Kumar et al., (2017). So to investigate the level of colonization of AM fungi in root plants, different districts of Punjab were surveyed in kharif and spring season.

\section{Materials and Methods}

\section{Survey for AM fungus}

The different Mungbean growing districts viz; Faridkot, Ferozepur, Ludhiana and Moga etc 
were surveyed during spring and kharif seasons in 2017. The rhizosphere soil samples along with complete healthy plants having well developed roots were collected in different polythene bags. All the collected samples were examined in the laboratory to observe AM colonization in root segments and spore population from the soil samples.

\section{Root colonization and spore population}

The mycorrhizal colonization was observed through staining of roots according to the procedure of Phillips and Hayman (1970). The AM infection was measured by the method suggested by Biermann and Lindermann (1981). The spores of AM fungi were extracted by wet sieving and decanting technique of Gerdemann and Nicolson (1963). The spore population was counted using counting dish from $25 \mathrm{ml}$ spore suspension.

\section{Results and Discussion}

\section{AM fungi root colonization}

Different Mungbean growing areas of Punjab were surveyed to observe the AM fungus colonization in Mungbean and spore population in rhizosphere soil of the crop. The samples of healthy plants along with soil were collected from Amritsar, Barnala, Bathinda, Faridkot, Ferozepur, Ludhiana, Mansa, Moga, Patiala, Sangrur, Shri Muktsar Sahib and Tarn-Taran districts of Punjab during spring season in 2017 whereas Faridkot, Ferozepur, Ludhiana, Moga and Patiala districts were surveyed during kharif 2017. The average percentage colonization along with spore population of AM fungus was recorded (Table 1 and 2). The samples from Ferozepur district showed maximum colonization of 80 per cent followed by $78,76,60,70,65,64$, $61,54,51,44$ and 27 per cent colonization in the samples collected from Faridkot, Tarn-
Taran, Patiala, Moga, Amritsar, Ludhiana, Shri Muktsar Sahib, Mansa, Barnala and Bathinda districts during spring 2017, respectively. Similarly, in kharif 2017, maximum mycorrhizal colonization was 78 per cent in samples collected from Ferozepur district followed by 77, 69, 60 and 58 per cent colonization in the samples of Faridkot, Moga, Ludhiana and Patiala districts. The minimum colonization of 27 and 58 per cent was recorded from the samples collected from Bathinda and Patiala districts in spring and Kharif season, respectively (Fig. 1 and 2). The samples collected form Faridkot, Ferozepur, Ludhiana and Moga districts in spring season exhibited less mycorrhizal colonization as compared to kharif season is same districts. The percentage colonization was significantly different from each other with respect to the samples collected from different districts. Singh and Singh (2001) reported maximum colonization of 72.5 per cent in the root samples collected from Ludhiana followed by 67.2, 65.9, and 64.6 per cent colonization from the samples of Bathinda, Jalandhar and Faridkot. The minimum colonization of 55 per cent was observed from the sample of Hoshiarpur. Then, Hindumuthi and Reddy (2012) observed mycorrhizal colonization in Mungbean plants collected from Adilabad, Nizamabad and Karimnagar districts of Andhra Pardesh. The mycorrhizal colonization was varied from 36.74 to 90.68 per cent in Mungbean roots.

\section{Spore population}

The highest spore population was 800 and 780 spores per $100 \mathrm{~g}$ rhizosphere soil sample that was collected from Ferozepur district during spring and kharif 2017 seasons. The minimum spore populations were 125 and 450 spores per $100 \mathrm{~g}$ rhizosphere soil in the samples of Bathinda and Patiala districts during spring and kharif seasons, respectively 
(Fig. 2 and 4). The spore population recorded in various districts in spring and kharif seasons was statistically significantly different from each other.

Hindumathi and Reddy (2012) found that the spore population was ranged from 12 to 89 spores per $10 \mathrm{~g}$ soil in rhizosphere soil samples collected form Mungbean field in Adilabad, Nizamabad and Karimnagar districts of Andhra Pradesh. The spores of Glomus spp. were found predominant in all the samples collected from different districts of Punjab in spring and kharif seasons.

Table.1 Root colonization and spore population of Arbuscular Mycorrhizal fungus in different Mungbean growing areas of Punjab in spring 2017 season

\begin{tabular}{|c|c|c|c|c|c|}
\hline Districts & $\begin{array}{c}\text { Colonization } \\
(\%)\end{array}$ & Mycelium & $\begin{array}{c}\text { Arbuscule } \\
\text { S }\end{array}$ & Vesicles & Total \\
\hline Amritsar & $65.00(53.70)$ & ++ & ++ & +++ & 475.00 \\
\hline Barnala & $44.00(41.50)$ & ++ & + & + & 250.00 \\
\hline Bathinda & $27.00(31.20)$ & + & + & + & 125.00 \\
\hline Faridkot & $78.00(62.00)$ & +++ & +++ & +++ & 675.00 \\
\hline Ferozepur & $80.00(63.50)$ & +++ & +++ & +++ & 800.00 \\
\hline Ludhiana & $61.00(51.30)$ & ++ & ++ & +++ & 475.00 \\
\hline Mansa & $51.00(45.50)$ & ++ & + & ++ & 300.00 \\
\hline Moga & $70.00(56.70)$ & +++ & ++ & +++ & 600.00 \\
\hline Shri Muktsar & $54.00(47.20)$ & ++ & + & ++ & 350.00 \\
\hline Sahib & & & & & \\
\hline Patiala & $60.00(50.75)$ & ++ & ++ & +++ & 430.00 \\
\hline Sangrur & $64.00(54.11)$ & ++ & ++ & ++ & 500.00 \\
\hline Tarn-Tarn & $76.00(62.00)$ & +++ & ++ & +++ & 625.00 \\
\hline C D at 5\% & 3.08 & & & & 67.42 \\
\hline
\end{tabular}

$+=$ Scanty $;++=$ Moderate $;+++=$ Abundant

Figures in parentheses are arc sin transformed value of respective data

Table.2 Root colonization and spore population of Arbuscular Mycorrhizal fungi in different mungbean growing areas of Punjab during kharif season

\begin{tabular}{|c|c|c|c|c|c|}
\hline Districts & $\begin{array}{c}\text { Colonization } \\
(\boldsymbol{\%})\end{array}$ & Mycelium & Arbuscules & Vesicles & Total \\
\hline Faridkot & $77.0(61.34)$ & +++ & ++ & +++ & 660.0 \\
\hline Ferozepur & $78.0(62.06)$ & +++ & ++ & +++ & 780.0 \\
\hline Ludhiana & $60.0(50.75)$ & ++ & + & ++ & 450.0 \\
\hline Moga & $69.0(56.16)$ & ++ & + & +++ & 560.0 \\
\hline Nabha & $58.0(49.25)$ & +++ & + & ++ & 450.0 \\
\hline CD at 5 \% & 3.45 & & & & 34.97 \\
\hline
\end{tabular}

$+=$ Scanty $;++=$ Moderate $;+++=$ Abundant

Figures in parentheses are arc sin transformed value of respective data 
Fig.1 Colonization of Arbuscular Mycorrhizal fungi in different districts of Punjab in spring Season

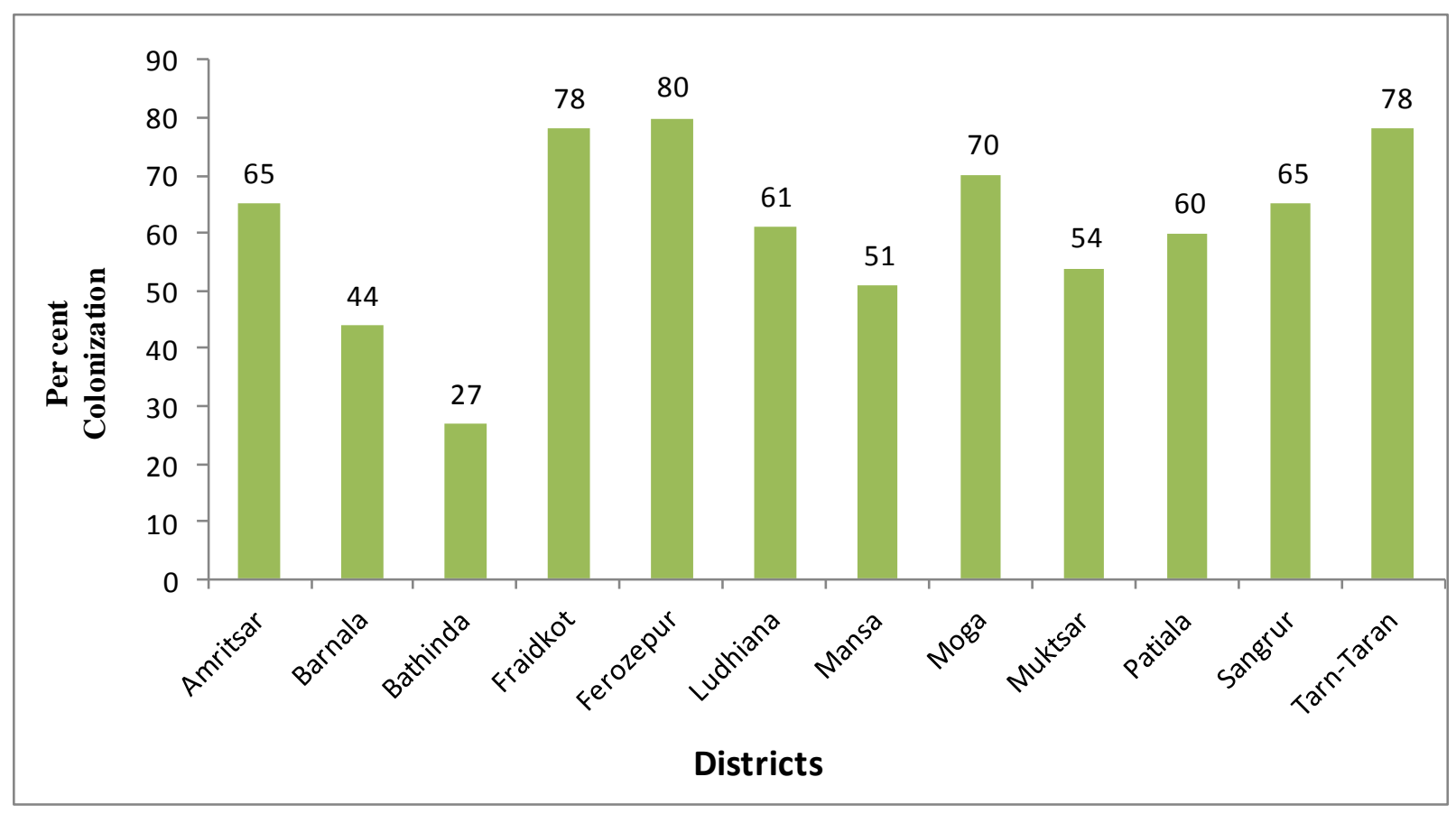

Fig.2 Total number of Arbuscular Mycorrhizal spores in different districts of Punjab in spring season

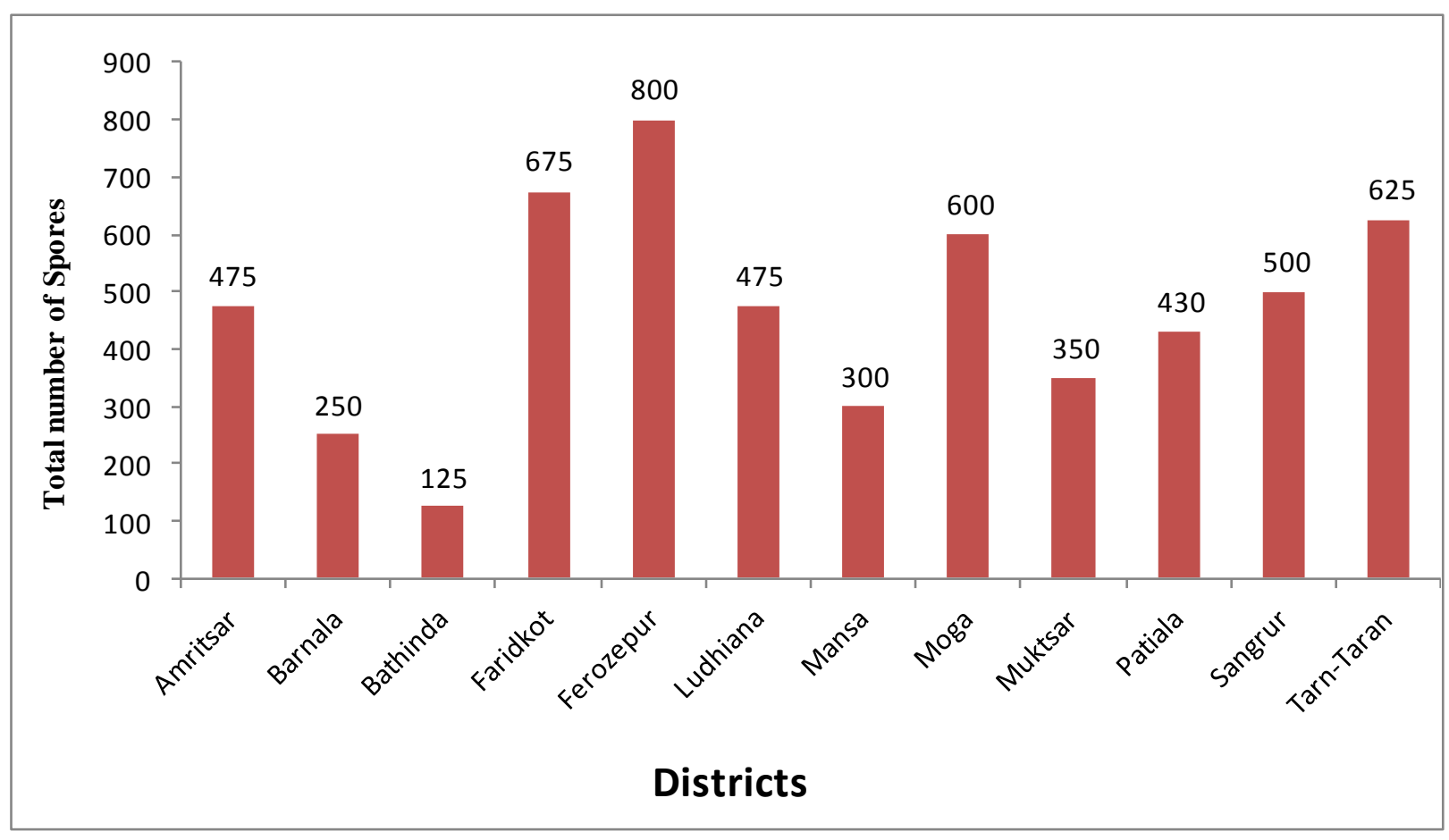


Fig.3 Colonization of Arbuscular Mycorrhizal fungi in different districts of Punjab in kharif season

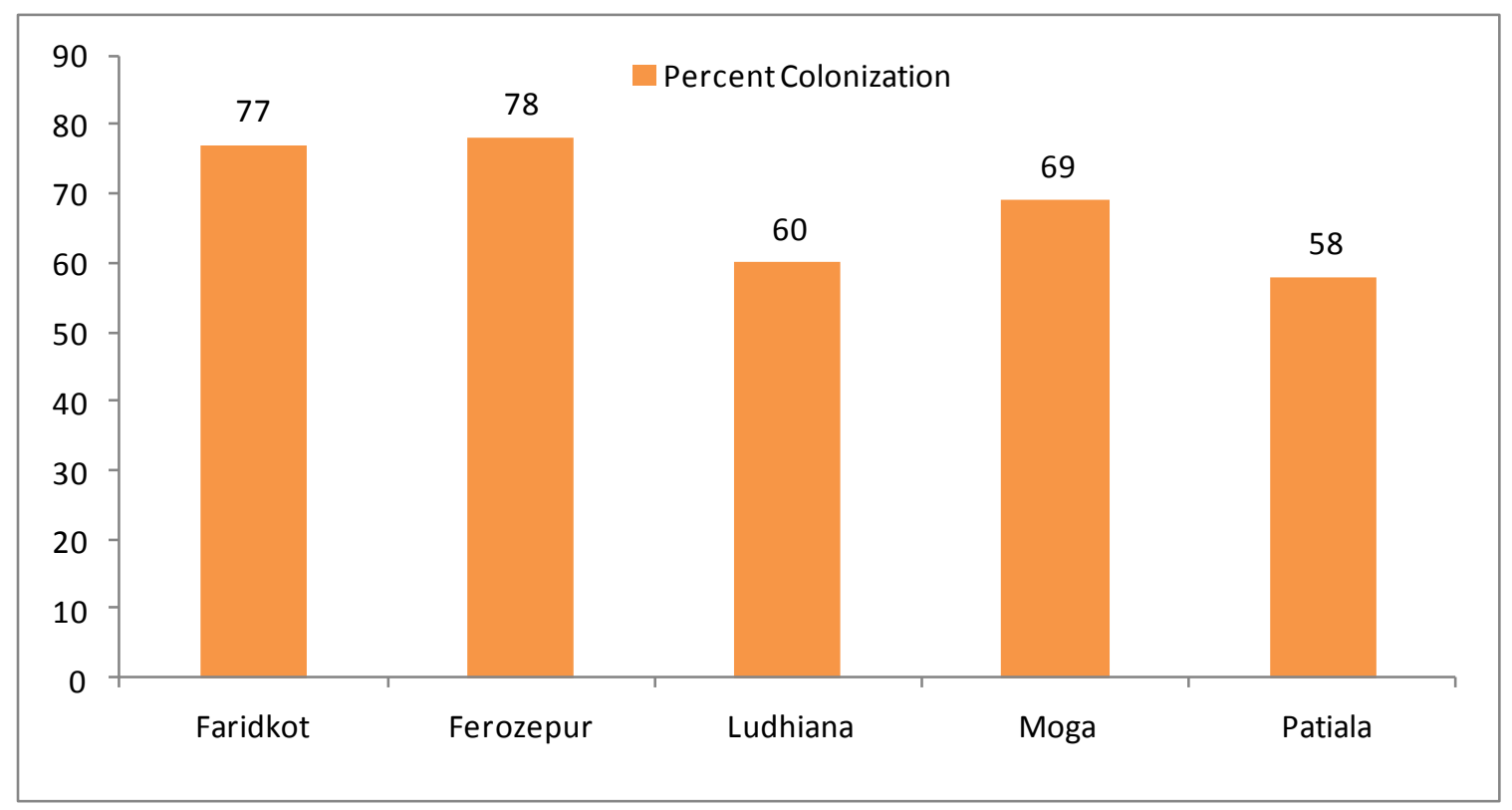

Fig.4 Total number of Arbuscular Mycorrhizal spores in different districts of Punjab in kharif season

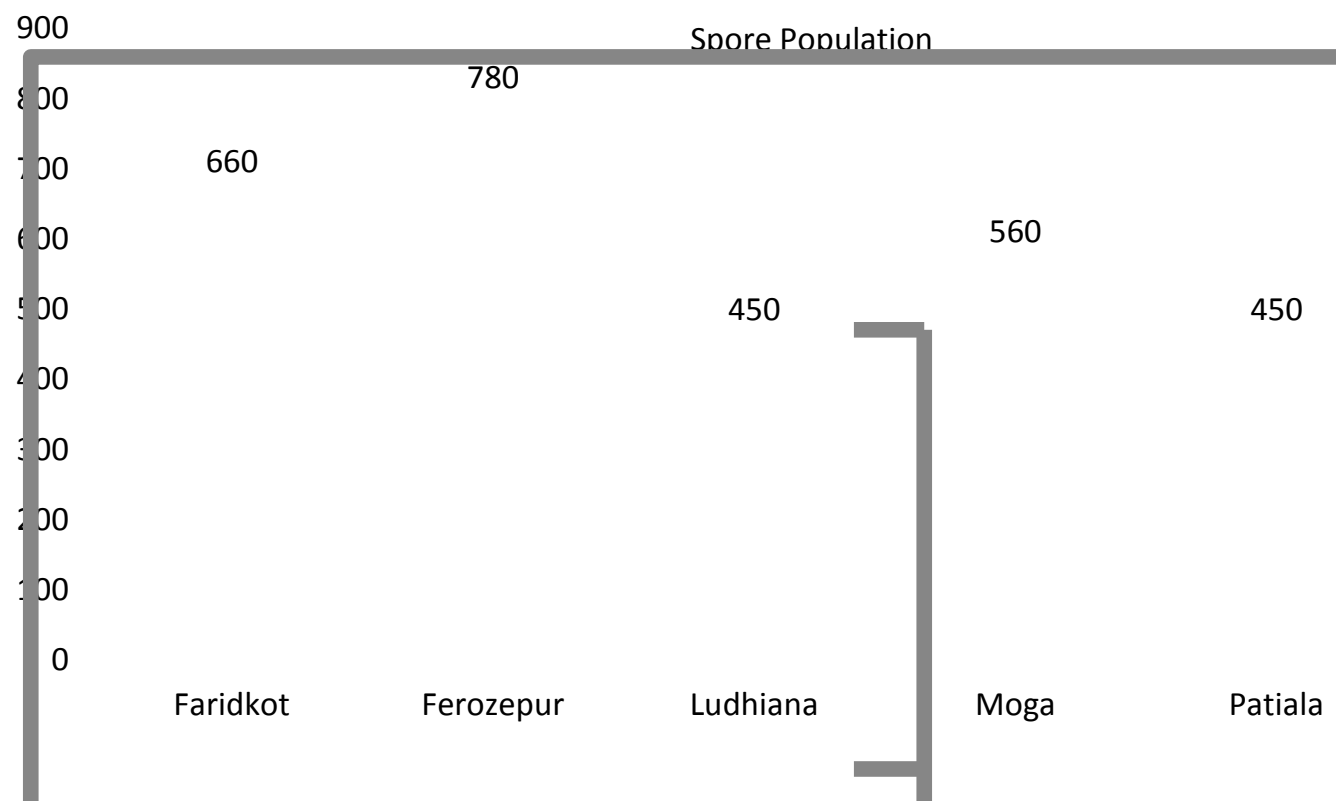

The spore population of Glomus spp. varied from 76.72 to 440.29 from samples of Bathinda and Ferozepur districts in spring season, respectively. But in kharif season, the spore population varied from 170.34 to 398.24 in samples collected from Patiala and Ferozepur districts. Singh and Singh (2001) observed the highest spore population (485 
spores per 50g) of VAM fungus in the rhizosphere soil collected from Ludhiana district. It was minimum (360 spores per 50g) of soil in the sample of Hoshiarpur district.

Regarding mycorrhizal structures like mycelium, they were present in moderate form during spring and abundantly during kharif season. The arbuscules were observed again in moderate form in spring and kharif seasons in thinner rootlets. After that, the thicker stained root samples exhibited vesicle storage structure that were present abundantly in the host root tissue in spring and kharif seasons, respectively. The vesicles were elongated, present inter-cellularly in root tissues. Hindamuthi and Reddy (2012) observed the abundant presence of mycelium, moderate number of vesicles and arbuscules of AM fungus in root samples collected from Mungbean crop during summer season.

\section{References}

Biermann B and Lindermann R G (1981) Quantifying arbuscular mycorrhizae: A proposed method towards standardization. New Phytol 87: 6367.

Gerdemann J W and Nicolson T H (1963) Spores of mycorrhizal Endogone species extracted from soil by wet sieving and decanting. Trans Br Mycol Soc 46: 235-44.

Hindumathi A and Reddy B N (2012)
Synergistic effect of arbuscular mycorrhizal fungi and Rhizobium on the growth and charcoal rot of soybean (Glycine max). World J Sci Technol 2: 1-9.

Kumar S, Yadav S S, Tripura P, Jinger D and Balwan (2017) Interaction effect of phosphorus and bio-organics for increasing productivity and profitability of mungbean (Vigna radiata L. Wilczek). Ann Agric Res 38: 67-72

Manke N M, Potdukhe S R, Bramhankar S B and Padghan P R (2008) Effect of rhizobidm and VAM on growth parameters and yield of mungbean. $J$ Pl Dis Sci 3: 185-88.

Phillips J M and Hayman D S (1970) Improved procedures for clearing roots and staining parasitic and VA mycorrhizal fungi for rapid assessment of infection. Trans $\mathrm{Br}$ Mycol Soc 55:158-61.

Singh D and Singh R S (2001) Incidence of vesicular-arbuscular mycorrhizal fungi in chickpea in Punjab. Pl Dis Res 16: 107-09.Wang B and Qiu Y L (2006) Phylogenetic distribution and evolution of mycorrhizae in land plants. Mycorrhiza 16: 299-63.

Wang B and Qiu Y L (2006) Phylogenetic distribution and evolution of mycorrhizae in land plants. Mycorrhiza 16: 299-63.

\section{How to cite this article:}

Amandeep Singh, Daljeet Singh Buttar and Randeep Singh. 2020. Assessment of AM Fungi Colonization and Spore Population in Different Mungbean Growing Areas of Punjab. Int.J.Curr.Microbiol.App.Sci. 9(04): 152-157. doi: https://doi.org/10.20546/ijcmas.2020.904.019 